\title{
臨床研究 II
}

\section{大腸癌肝転移に対する $5-\mathrm{FU}+\mathrm{CDDP}$ 療法の検討}

\begin{tabular}{|c|c|c|c|c|c|c|c|c|c|c|}
\hline \multicolumn{11}{|c|}{ 金沢大学第 1 外科 } \\
\hline 由 & 文 & 生 & 大 & 村 & 健 & 二 & 金 & 平 & 永 & 二 \\
\hline 本 & 琭 & 生 & 渡 & 辺 & & 透 & 平 & 野 & 勝 & \\
\hline 辺 & 俊 & 一 & 渡 & 辺 & 洋 & 宇 & & & & \\
\hline
\end{tabular}

切除不能大腸癌旰転移11例に対し， 5-FU + CDDP 療法を行った。 うち 7 例は CDDP 50 $\mathrm{mg} / \mathrm{body} /$ day の持続静脈内投与 2 日間に $5-\mathrm{FU} 375 \mathrm{mg} / \mathrm{m}^{2} /$ day 6 日間併用し，以後 3 週間, UFT $400 \mathrm{mg} /$ day を経口的に投与して，4週間を 1 クールとした４例は 5-FU500mg/body/ day の持続静脈内投与か，または UFTE $600 \mathrm{mg} /$ day の連日経口投与に CDDP $10 \mathrm{mg} /$ day を 5 投 2 休で静脈内点滴投与して，4週間を1クールとした。なお肝動脈内投与あるいは門脈内投 与には全身投与の $1 / 2$ 量を用いた。結果は, PR が 3 例, NC が 3 例, PD が5例であり, 奏効率は $27 \%$ であった。 1 年生存率は $72 \% ， 50 \%$ 生存期間は14力月であった，5-FU十 CDDP 療法を行った群の生存率が，本療法以外の化学療法が施行された $\mathrm{H}_{2}, \mathrm{H}_{3}$ 症例，15例 に比へ統計学的に有意に良好な結果 $(p<0.05)$ が得られた．本療法は大腸癌肝転移に対して 有効な化学療法と思われた。

索引用語 : 大腸癌肝転移, $5-\mathrm{FU}+\mathrm{CDDP}$ 療法

\section{はじめに}

近年，大腸内視鏡検查の進步上便潜血反応検查 の普及などにより, 初期病变の大腸癌が診断, 治 療される機会が増加しつつある.しかし，一万で は遠隔転移を伴い治瘉切除不能な大腸癌症例も依 然として多くを占めている1．かかる遠隔移転に 対しては，これまでフッ化ピリミジン系の抗癌剤 をはじめ, 種々の化学潦法が行われているが，い まだ満足すべき結果をみない2．教室では切除不 能の大腸癌肝転移に対して5-FU，シスプラチ ン併用療法（以下 $5-\mathrm{FU}+\mathrm{CDDP}$ 療法）を行 い，良好な結果をえているので報告する。

\section{I. 対象および方法}

切除不能の肝転移を伴う大腸癌症例で，原発巣 が切除可能な症例か，あるいはすでに原発巣は切
除されており肝転移再発した症例を対象とした。 1990年 3月から1993年12月までに11例に対して $5-\mathrm{FU}+\mathrm{CDDP}$ 療法を施行した（表 $1 ， 2$ ）. 性別は男性 6 例, 女性 5 例で, 年齢は34歳から74 歳，平均年齢は59 14歳であった。大腸癌占居部 位は上行結腸 2 例, 下行結腸 1 例, $\mathrm{S}$ 状結腸 5 例，直腸 3 例であった，肝転移の程度は $\mathrm{H}_{2}$ が 5 例, $\mathrm{H}_{3}$ が 6 例で, 同時性 (12力月未満) 旰転移 10例，異時性肝転移 1 例であった，併存する他の

表 $1 \quad 5-F U+C D D P$ 療法 投与スケジュール

1) middle dose $\mathrm{CDDP}+5-\mathrm{FU}$ 湶法 CDDP $50 \mathrm{mg} / \mathrm{body} /$ day CIV (day $1-2$ ) $5 \mathrm{FU} 375 \mathrm{mg} / \mathrm{m}^{2} /$ day $/ \mathrm{CIV}$ (day $2-7$ ) U F T $400 \mathrm{mg} /$ body/day PO (day $8-28$ )

2) low dose CDDP +5 -FU 療法 (for 4 weeks) CDDP 10mg/body/day DIV (day $1-5$ ) 5 FU 500mg/body/day CIV (day $1-7$ ) or UFTE $600 \mathrm{mg} / \mathrm{body} / \mathrm{day}$ PO (day $1-7$ ) 
表 2 大腸癌肝転移に対する $5-F U+C D D P$ 療法の成績

\begin{tabular}{|c|c|c|c|c|c|c|}
\hline 年歯, 性 & 肝 転 移 & $\begin{array}{l}\text { 原発亲占龺部位, 進行度 } \\
\text { 組織型, 術式 }\end{array}$ & $\begin{array}{l}\text { 投尔 } \\
\text { 経路, 回数 }\end{array}$ & $\begin{array}{l}\text { middle or } \\
\text { low dose }\end{array}$ & 奏効度 & 予 後 \\
\hline $1: 49 \mathrm{~F}$ & 同洔性 $\mathrm{H}_{3}$ & $\begin{array}{l}\mathrm{Rb}, 2 \text { 型, } \mathrm{P}_{3} \mathrm{~S}_{2} \mathrm{~N}_{2} \\
\text { well, 詿験開腹 }\end{array}$ & 静注- 2 & low & $\mathrm{PD}$ & $8 \mathrm{M}$ alive \\
\hline $2: 35 \mathrm{~F}$ & 同時性 $\mathrm{H}_{3}$ & $\begin{array}{l}\mathrm{A}, 2 \text { 型, } \mathrm{P}_{0} \mathrm{~s} \mathrm{n}_{3} \\
\text { well, 石半結腸切除 }\end{array}$ & $\begin{array}{l}\text { 動注-2 } \\
\text { 静注-3 }\end{array}$ & $\begin{array}{l}\text { low } \\
\text { low }\end{array}$ & PR & $13 \mathrm{M}$ alive \\
\hline $3: 74 \mathrm{M}$ & 同時性 $\mathrm{H}_{2}$ & $\begin{array}{l}\mathrm{S}, 3 \text { 型， } \mathrm{P}_{0} \mathrm{Ssn}_{2} \\
\mathrm{mod} \text {, 状結腸切除 }\end{array}$ & 門注- 1 & low & $\mathrm{NC}$ & $7 \mathrm{M}$ died \\
\hline $4: 67 \mathrm{~F}$ & $\begin{array}{l}\text { 異時性 } \mathrm{H}_{3} \\
12 \mathrm{M}\end{array}$ & $\begin{array}{l}\mathrm{A}, \quad 3 \text { 型, } \mathrm{P}_{0} \mathrm{ssn}_{2} \\
\text { muc, 右半結腸切除 }\end{array}$ & 静注- 1 & low & $\mathrm{PD}$ & $3 \mathrm{M}$ died \\
\hline $5: 54 \mathrm{M}$ & 同時性 $\mathrm{H}_{2}$ & $\begin{array}{l}\mathrm{S}, 2 \text { 型, } \\
\bmod \text {, 状結腸切除 }\end{array}$ & $\begin{array}{l}\text { 動注-1 } \\
\text { 静注-1 }\end{array}$ & $\begin{array}{l}\text { middle } \\
\text { middle }\end{array}$ & $\mathrm{PR}$ & $24 \mathrm{M}$ died \\
\hline $6: 73 \mathrm{~F}$ & 同時性 $\mathrm{H}_{2}$ & $\begin{array}{l}\mathrm{S}, 2 \text { 型, } \mathrm{P}_{0} \mathrm{Ssn}_{\mathrm{I}} \\
\mathrm{mod} \text { 状結腸切除 }\end{array}$ & 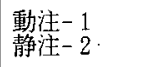 & $\begin{array}{l}\text { middle } \\
\text { middle }\end{array}$ & $\mathrm{PD}$ & $14 \mathrm{M}$ died \\
\hline $7: 70 \mathrm{M}$ & $\begin{array}{l}\text { 同時性 } \mathrm{H}_{2} \\
\text { (肺転移) }\end{array}$ & $\begin{array}{l}\mathrm{D}, 3 \text { 型, } \mathrm{P}_{0} \mathrm{ssn}_{0} \\
\mathrm{mod}, \mathrm{t} \text { 半結腸切除 }\end{array}$ & $\begin{array}{l}\text { 動注-1 } \\
\text { 静注-1 }\end{array}$ & $\begin{array}{l}\text { middle } \\
\text { middle }\end{array}$ & $\mathrm{PR}$ & $14 \mathrm{M}$ died \\
\hline $8: 62 \mathrm{M}$ & 同時性 $\mathrm{H}_{3}$ & $\begin{array}{l}\mathrm{Rb}, 3 \text { 型, } \\
\text { well, 低位前方切除 }\end{array}$ & 静注- 1 & middle & $\mathrm{NC}$ & $13 \mathrm{M}$ died \\
\hline $9: 74 \mathrm{M}$ & 同時性 $\mathrm{H}_{2}$ & $\begin{array}{l}\mathrm{Rb}, 2 \text { 型, } \mathrm{P}_{0} \mathrm{ssn} \\
\text { well, } \text { 低位前方切除 }\end{array}$ & 静注- 1 & middle & $\mathrm{NC}$ & $19 \mathrm{M}$ died \\
\hline $10: 34 \mathrm{~F}$ & $\begin{array}{l}\text { 同時性 } \mathrm{H}_{3} \\
\text { (肺, 即覓転移) }\end{array}$ & $\begin{array}{l}\mathrm{S}, 3 \text { 型, } \mathrm{P}_{0} \sin _{2}{ }_{\mathrm{mod}} \mathrm{S} \text { 状結腸切除 }\end{array}$ & $\begin{array}{l}\text { 動注-1 } \\
\text { 静注- } 2\end{array}$ & $\begin{array}{l}\text { midle } \\
\text { middle }\end{array}$ & $\mathrm{PD}$ & $10 \mathrm{M}$ died \\
\hline $11: 61 \mathrm{M}$ & 同時性 $\mathrm{H}_{3}$ & $\begin{array}{l}\mathrm{S}, 2 \text { 型, } \mathrm{P}_{0} \mathrm{pmn}_{\mathrm{O}} \\
\text { well, 低位前方切除 }\end{array}$ & 静注- 1 & middle & $\mathrm{PD}$ & $15 \mathrm{M}$ died \\
\hline
\end{tabular}

表 3 背景因子の比較

遠隔転移として肺転移が 2 例にみられた。

大腸癌診断時すでに肝転移のあった症例には原 発巣切除後 3 ないし 4 週目に, 原発巣切除後肝転 移が発見された症例には，診断後ただちに化学療 法を開始した（表 1)。11例中 7 例は，CDDP 50 $\mathrm{mg} / \mathrm{body} / \mathrm{day} の$ 持続静脈内投与 2 日間（day 1，2）に $5-\mathrm{FU} 375 \mathrm{mg} / \mathrm{m}^{2} /$ day 6 日間（day $2-7$ ) 併用L, 以後 3 週間, UFT400mg/dayを 経口的に投与した (middle dose 群). 後半の 4 例は，5-FU500 mg/body/day $の$ 持続静脈内投 与か，またはUFTE $600 \mathrm{mg} / \mathrm{day}$ （分 2）の連日 経口投与に CDDP $10 \mathrm{mg} / \mathrm{day}$ を 5 投 2 休で静脈内 点滴投与して，4 週間を 1 クールとした（low dose 群). なお肝動脈内投与あるいは門脈内投与 には全身投与の $1 / 2$ 量を用いた．以上の化学療 法を11例に対し，合計22回施行した。

大腸癌の記載は大腸癌取扱い規約3)に従い，肝 移転に対する化学療法の効果判定は, 腹部 CT ス キャン上の腫瘍径の変化から日本癌治療学会の固 形がん化学療法直接効果判定基準4に従って判定 した，生存率は日本癌治療学会・癌規約総論 5 に 従ってカプランマイヤー法により求め, 統計学的 な有意差を一般化ウィルコクソン検定にて判定し た。 また当科で経験した切除不能大腸癌肝転移 で，5-FU+CDDP 療法以外の化学療法が施行

\begin{tabular}{|c|c|c|c|}
\hline \multicolumn{2}{|c|}{ 背景因子 } & CDDP+ 5 -FU 群 & 対照群 \\
\hline \multicolumn{4}{|c|}{ 原発果占居部位 } \\
\hline \multicolumn{2}{|c|}{$\mathrm{A}$} & 2 & 1 \\
\hline \multicolumn{2}{|c|}{$\mathrm{T}$} & 0 & 0 \\
\hline \multicolumn{2}{|c|}{$\mathrm{D}$} & 1 & 0 \\
\hline \multicolumn{2}{|c|}{$S$} & 5 & 2 \\
\hline \multicolumn{2}{|c|}{$\mathrm{R}$} & 3 & 12 \\
\hline \multirow[t]{4}{*}{ 肝 } & 移 $\mathrm{H}_{2}$ & 5 & 5 \\
\hline & $\mathrm{H}_{3}$ & 6 & 10 \\
\hline & 同時性 & 10 & 10 \\
\hline & 異時性 & 1 & 5 \\
\hline \multicolumn{4}{|c|}{ 化学療法 } \\
\hline \multicolumn{2}{|c|}{$\mathrm{MFC}^{*}$} & & 7 \\
\hline \multicolumn{2}{|r|}{$5-\mathrm{FU}$} & & 3 \\
\hline \multicolumn{2}{|r|}{ その他 } & & 5 \\
\hline \multicolumn{2}{|c|}{ 年＼cjkstart齢 } & $59 \pm 14$ & $54 \pm 11$ \\
\hline \multirow[t]{2}{*}{ 性 号 } & 男 性 & 6 & 9 \\
\hline & 女 性 & 5 & 6 \\
\hline \multirow[t]{4}{*}{ PS } & 0 & 0 & 0 \\
\hline & 1 & 6 & 5 \\
\hline & 2 & 5 & 10 \\
\hline & $3-4$ & 0 & 0 \\
\hline
\end{tabular}

$\mathrm{MFC}^{*}$ : MMC $2-4 \mathrm{mg}, 5-\mathrm{FU} 250 \mathrm{mg}, \quad \operatorname{AraC} 40 \mathrm{mg}$ iv

された $\mathrm{H}_{2}, \mathrm{H}_{3}$ 症例，15例を対照群とした。なお 5-FU + CDDP 療法群と対照群の背景因子に差 はみられなかった（表 3 ）。

\section{II. 結 果}

臨床効果判定では, 全体で奏効度 PR が 3 
表 $45-\mathrm{FU}+\mathrm{CDDP}$ 療法の効果判定

\begin{tabular}{|c|c|c|c|c|}
\hline $5-F U+C D D P$ 療法 & $\mathrm{PR}$ & $\mathrm{NC}$ & PD & 奏効率 \\
\hline middle dose 群 & 2 & 2 & 3 & $29 \%$ \\
\hline low dose 群 & 1 & 1 & 2 & $25 \%$ \\
\hline 全 & 3 & 3 & 5 & $27 \%$ \\
\hline
\end{tabular}

例， $\mathrm{NC}$ が 3 例， PD が 5 例であり，奏効率は 27 \%であった. そのうち middle dose 群では, 奏 効度 PR が 2 例, $\mathrm{NC}$ が 2 例, PD が 3 例であ り, 奏効率は29\%であった. low dose 群では, 奏効度 PR が 1 例, NC が 1 例, PD が 2 例で, 奏効率は25\%であり，両群ともほぼ同等の結果を 示した（表 2，4）. 図1には $5-\mathrm{FU}+\mathrm{CDDP}$ 療法群上対照群との生存率を比較した。 1 年生存 率は 5-FU+CDDP 療法群 $72 \%$, 対照群 $20 \%$ で あった. $50 \%$ 生存期間は $5-\mathrm{FU}+\mathrm{CDDP}$ 療法群 14 力月, 対照群 7 力月であった。 また $5-\mathrm{FU}+$ CDDP 療法を行った PR 3 例の生存期間はいず れも13力月を上回った。 $5-\mathrm{FU}+\mathrm{CDDP}$ 療法群 の生存率は, 対照群に比べ統計学的に有意に良好 であった. $(\mathrm{p}<0.05)$. しかし，5-FU+CDDP 療法群も対照群と同樣, 2 年以降の生存はほとん ど得られず, $\mathrm{H}_{2}, \mathrm{H}_{3}$ 症例に対する化学療法の困 難性がうかがわれた。

副作用としては顆粒球減少, 血小板減少などの 骨髄抑制と食欲不振などの消化器症状がみられた が，いずれも保存療法により改善しており，副作 用のために化学療法を中止した症例はなかった。

\section{III. 考察}

大腸癌肝転移に対する治療は, 外科的切除が最 も優れているが6)，臨床的に診断される肝軾移の なかで切除可能症例の割合は少ない，肝転移の多 くを占める, 切除不能な $\mathrm{H}_{2}, \mathrm{H}_{3}$ 症例に対しては 抗癌刜の全身ないしは局所投与に頼らざるを得な い. 単剤化学療法については, Haskell 7)が7,762 例の大腸癌症例を対象にした結果を報告している が，全身投与で明らかに有用と判定できる薬剤は なかったと結論している. 現在, それら薬剤のな かではフッ化ピリミジン系抗癌剂, とりわけ 5 FU が広く用いられ，大腸癌肝転移に対する5$\mathrm{FU}$ 全身投与の結果は，おおよそ 8 お $20 \%$ 前後と されるマ. 多剂併用化学療法については, 本邦で

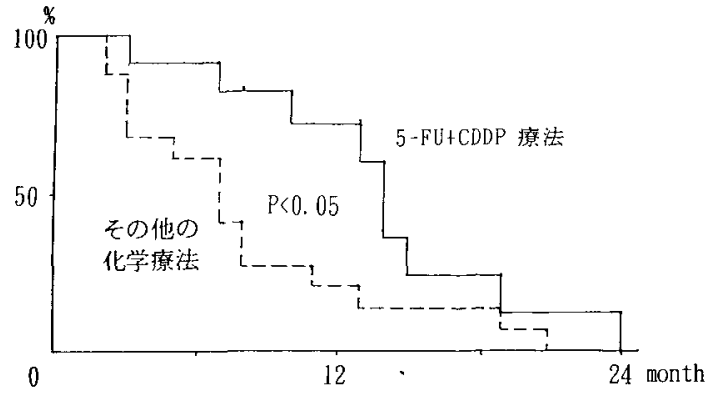

図 1 化学療法による生存率の比較 $\left(\mathrm{H}_{2}, \mathrm{H}_{3}\right.$ 症例 $)$

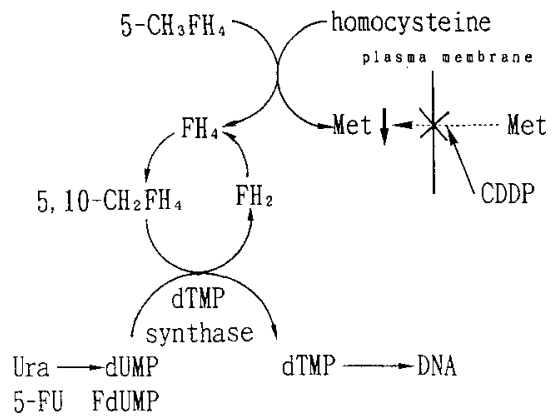

ternary complex: $>_{\mathrm{TS}}^{\mathrm{FdUMP}}-5,10-\mathrm{CH}_{2} \mathrm{FH}_{4}$

図2 5-FU + CDDP 療法の作用機序

は5-FUに Leucovorin や MTXを組み合わせ た併用療法の報告8,93が多い。しかし，大腸癌に 対する効果, 生存期間について 5 -FU 単独投与 に比べ明らかに改善されたとするものはな (2.7-9). その中で最近注目されているひとつが $5-\mathrm{FU}+\mathrm{CDDP}$ 療法である.

5-FU の主な抗腫瘍効果は, 5-FUから生成 される FdUMP が細胞内 $\mathrm{CH}_{2} \mathrm{FH}_{4}$, thymidylate synthase(TS) と結合し, ternary complex （TC）を形成して TS を不活性化させ，腫瘍細 胞の DNA 合成を阻害する点にある10)(風 2 ). TS 阻害率は細胞内 $\mathrm{CH}_{2} \mathrm{FH}_{4}$ 濃度に依存してお り, $\mathrm{TC}$ の形成には充分な細胞内 $\mathrm{CH}_{2} \mathrm{FH}_{4}$ が不 可欠である11-13)。一方, CDDP は, メチオニン を含む中性アミノ酸の細胞内への輸送を阻害し, 細胞内 $\mathrm{CH}_{2} \mathrm{FH}_{4}$ と葉酸プールを增加させて TC の形成を六進, 安定化させる14,15) (図 2)。この biochemical modulationを応用した化学療法 が, 近年, 進行・再発消化器癌に対して行われる

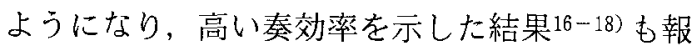


告されるようになった。

当初, 著者らは middle dose CDDP (50mg/ body/day, day 1，2）の投与を 5-FUに対す る modulator として用いた。 しかし，CDDP の modulator 効果として, 少量反復投与により 中等量単回投与と同等の效果が得られることが, 基礎的実験19)により示されたため，水付加の必要 がなく外来でも投与可能な low dose CDDP（10 $\mathrm{mg} /$ day, day $1-5 ， \dot{4}$ 週間) の投与に変更した。 middle dose 群では, 7 例中 2 例 $(29 \%)$, low dose 群では，4例中， 1 例 (25\%) にPR がえ られ，同様の奏効度を示した（表 $2 ， 4$ ）。さ に症例を加えた㭘討を行いたい。

今回，著者らが報告した27\%の奏效率は大腸澏 肝転移に対する従来の化学潦法"2)に比べ良好であ り，また他の $5-F U+C D D P$ 療法の報告とほぼ 同等の優れた結果であった。一方で，この化学療 法が高い奏效率を示しながら，必ずしも患者の予 後改善に貢献しない上する報告2.17, 18)もあり，検 討すべき問題となっている。 今回報告した 5 FU + CDDP 療法群O 1 年生存率は $72 \%, 50 \%$ 生存期間は14力月であり，PR 3 例の生存期間は いずれも13力月を上回る良好な結果が得られた。 症例数は少ないものの，5-FU +CDDP 療法群 の生存梁が，対照群に比べ統計学的に有意に良好 な結果であったことが注目される。しかし5$\mathrm{FU}+\mathrm{CDDP}$ 療法群，対照群ともに 2 年以上の 生存はほとんど得られておらず，大腸癌肝転移に 対する化学療法の困難性を改めて認識した。

教室では， $5-\mathrm{FU}+\mathrm{CDDP}$ 療法を症例の全身 状態が許す限り，繰り返し投与することにしてし ている，したがって長期生存の得られる症例で は，化学療法の回数も多い，今回報告したなか で，症例 2に対しては，5-FU+CDDP 療法を 合計 5 クール行っているが, うち3クールは外来 にて投薬しており，良好なQOLを維持しえた。 この症例は, 術後 13 力現在元気に外来通院して いる．かかる症例では合計した化学療法の期間が かなり長期となるため，化療前後を通しての QOL を良好に保つことが，生存期間の延長をめ ざすと同様に大切であり，今後の重要な課題であ ると思われた，本法は外来にて施行することも充 分可能なため，化学療法の期間を通じて癌治療患
者のQOLを良好に保ち得る有用な化学療法と思 われた。

\section{IV. ま亡 め}

切除不能の大晹癌肝転移11例に対して，5$\mathrm{FU}+\mathrm{CDDP}$ 療法を行った。 PR が 3 例, NCが 3 例, PDが 5 例であり，奏效率は $27 \%$ であっ た。 1 年生存率は $72 \% ， 50 \%$ 生存期間は 14 力 月で あった５-FU+CDDP 療法を行った群の生存 淘が， 5-FU + CDDP 療法以外の化学療法が施 行された $\mathrm{H}_{2}, \mathrm{H}_{3}$ 症例，15例に比べ統計学的に有 意に良好な結果（ $\mathrm{p}<0.05 ）$ が得られた。 5 FU + CDDP 療法は大腸癌肝転移に対して有効 な化学療法と思われた。

\section{文献}

1) Benstsson G, Carlsson G, Hafstrom, U, et al : Natural history of patients with unresected liver metastasis from colorectal cancer. Am J Surg 141:586-589, 1981

2）田口鐵男：薬剤之選択。北條慶一，近田千尋監 修, 大腸癌の化学療法. 東京, 癌と化療社, 1988, p 15-27

3）大腸癌研究会編：大腸癌取扱い規約。改訂第 4 版，金原出版，1985

4）日本癌治療学会: 固形癌化学療法直接効果判定 基準，日癌治療会誌 21：929-942，1986

5）日本癌治療学会 癌の治療に関する合同委員会 癌規約総論委員会編：日本癌治療学会・癌規約 総論, 金原出版, 1991

6）杉原健一, 北條慶一：肝転移の治療. 蹦床科学 $27: 159-163,1991$

7) Haskell CM : Cancer Treatment, pp 2953342 nd Ed. Saunders, Tokyo, 1985

8）太田和雄，村上稔：MTX・5-FUによる Biochemical Modulation. 癌と化潦 14 : $1642-1649,1987$

9）山村卓也, 花井 彰, 及川博活か：大腸癌肝 転移に対する5-FU，ロイコボリン併用動注 療法の検討。癌と化療 20:1516-1519，1993

10）白坂哲彦，島本雄司，木下英之ほか：5-FU 系抗癌郕とシスプラチンの併用による抗腫瘍効 果增強とその作用機序一 5-FU の Biochemical Modulationの立場から一. 癌と化療 $18: 403-409,1991$

11) Spears CP, Gustavsson BG, Berne M, et al : Mechanism of innate resistance to thymidylate synthase inhibition after 5 fluorouracil. Cancer Res 48:5894-5900, 1988

12) Dohden K, Ohmura K, Watanabe $Y$ : Ternary complex formation and reduced 
folate in surgical specimens of human adenocarcinoma tissues. Cancer $71: 471$ 480,1993

13）大村健二, 川上和之, 石田文生, ほか：UFT 投与による七ト結腸・直腸癌組織内チミジル酸 合成酵素の FdUMP binding site 数の変化々 葉酸プールの変動. 日外会誌 $94: 193,1993$

14) Cohn J, Tester $W$, Desai A, et al : Continuous infusion 5 -fluorouracil and weekly low dose cisplatin in metastatic gastrointestinal malignancies. Proc Am Soc Clin Oncol $7: 115,1988$

15) LoRusso P, Pazdur R, Redman BG, et al: Low-dose continuous infusion 5 -fluorouracil and cisplation: Phase Il evaluation in advanced colorectal carcinoma. Am J Clin Oncol (CCT) $12: 486-490$,
1989

16）大村健二，道伝研司，宗本義則ほか：シスプラ チン, 5 - FU (UFT) 併用療法による消化器 癌の治療，癌と化療 19:723-725, 1992

17) Kemeny N, Daly J, Reichman B, et al : Intrahepatic or sistemic infusion of fluorodeoxyuridine in patients with liver metastases from colorectal carcinoma. Ann Int Med 107: 459-465, 1987

18) Martin JK, O'Connell MJ, Wieand HS, et al: Intra-arterial fluoxuridine vs systemic fluorouracil for hepatic metastases from colorectal cancer. A randomized trial. Arch Surg 125: 1022-1027, 1990

19）橋本玩生：フッ化ピリミジン系抗がん剂の抗腫 婸効果増強に関する基礎的研究. 十全医会誌 $102: 658-670,1993$

\title{
5-FU and CDDP for Liver Metastases Originated from Colorectal Carcinoma
}

\author{
F. Ishida, K. Omura, E. Kanehira, T. Hashimoto, T. Watanabe, \\ K. Hirano, S. Watanabe and Y. Watanabe \\ First Department of Surgery, School of Medicine, \\ Kanazawa University, Kanazawa, Ishikawa
}

A combined chemotherapy with $5-F U$ and CDDP was performed in 11 cases with unresectable liver metastases of colorectal carcinoma. In 7 cases, CDDP $50 \mathrm{mg} / \mathrm{body} / \mathrm{day}$ CIV (days 1, 2 ) , 5 -FU $375 \mathrm{mg} / \mathrm{m}^{2} /$ day CIV (days 2 - 7 ) and UFT $400 \mathrm{mg} /$ day PO (days 8 -28) were administered for 1 period. In 4 cases, CDDP 50mg/body/day CIV (days 1 - 5 ) and 5 FU $500 \mathrm{mg} /$ body/day CIV (days 1 - 7 ) or UFTE $600_{\mathrm{mg}} /$ day PO (days 1 - 7 ) were administered for 4 weeks. A half-dose of systemic chemotherapy was administered through hepatic artery or through portal vein. The overall response rate was $27 \%$. One-year survival rate was $72 \%$ and median survival was 14 months. The survival rate of 11 cases treated by this therapy was statistically higher than that of 15 cases with $\mathrm{H}_{2}$ ro $\mathrm{H}_{3}$ liver metastases treated by conventional chemotherapy. These results suggest that $5-F U+C D D P$ therapy is effective in the treatment of liver metastasis of colorectal carcinoma. 